\title{
legelivet
}

På disse sidene i Tidsskriftet - legelivet - finner du stoff om legers liv.

Her er det presentasjon av arbeidssteder, nyhetssaker, nye doktorgrader,

nye spesialister og minneord. Alt samlet på ett sted - så du kan følge enda bedre med.

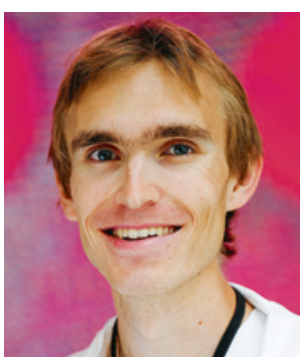

Frederik Emil Juul. Foto: Jon Olav Nesvold

Frederik Emil Juul (f. 1989) er turnuslege ved Skjåk legekontor.

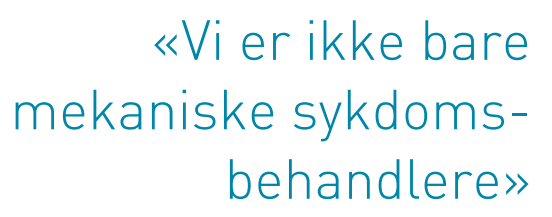

\section{Unike uniformer}

Selv om legefrakker er ganske så like, kommer leger i mange varianter.

Et klassisk bilde av en lege er en mann med hvit frakk og stetoskop rundt halsen. Jeg vil påstå at leger har sine egne karikerte oppfatninger av hvordan kolleger er kledd: Kirurgene rusler gjerne rundt $\mathrm{i}$ grønne operasjonsklær, uten legefrakk og med kun telefon og ID som medbrakt tilbehør. De hvitkledde indremedisinerne trekker oftere på seg legefrakk og legger gjerne et stetoskop samt en prosedyreveileder eller to i lommene. Turnuslegene er forberedt på det meste, og et stort armamentarium av utstyr, notater og veiledere gjør at frakkelommene buler.

Selv om uniformene hentes fra et felles lager og bare kommer i to farger, avslører ofte små detaljer noe om hvem vi er. For eksempel har jeg merket meg at sykepleiere ved flere barneavdelinger dekorerer ID-skiltene med klistremerker samt at leger med fargerik personlighet oftere har fargede stetoskop. Fotplaggene kommer også i mange varianter, alt fra tidløse Birkenstock-sandaler til mer praktiske joggesko. Hvor slitt, hvilket merke og (for de innvidde) hvilken skomodell man bruker, er med på å gi oss et bilde av personen som går med dem.

Til tross for overnevnte og andre variasjoner skifter vi til en mer profesjonell og nøytral rolle utad når vi tar på oss legeuniformen. Forhåpentligvis gir det en positiv forventning og trygghet hos pasientene. Samtidig tror jeg hintene om bakgrunn, interesser og personlighet bidrar til å vise oss som unike medmennesker - vi er ikke bare mekaniske sykdomsbehandlere.

\section{Frederik Emil Juul}

fejuul.medisin@gmail.com 